\title{
Evaluación de la actividad enzimática, morfológica y cambios fisicoquímicos en diferentes tipos de cebada germinada
}

\author{
Evaluation of enzymatic activity, morphological and physicochemical changes in germinated \\ barley at different times
}

Gutiérrez-Osnaya, Laura Jacqueline a, Guzmán-Ortiz, Fabiola Araceli a*, Román-Gutiérrez, Alma Delia a, Hernández-Uribe, Juan Pablo ${ }^{a}$

\begin{abstract}
:
Barley is the cereal of the room mostly grown, which provides us with essential compounds such as carbohydrates, lipids, proteins. It is used in the industry for its high starch content. Due to the fact that starch is unstable in several factors, nowadays we have opted for modifications to starch granules to improve functionality and expand its uses in the industry. However, children who have had their studies have undergone changes in the changes that the grains undergo during germination. That is why the influence of germination on the morphological changes that are generated in the granules of barley starch was analyzed (Esmeralda and Perla varieties).
\end{abstract}

Keywords:

Barley, germination, starch, modification

\section{Resumen:}

La cebada es el cuarto cereal mayormente cultivado, ya que nos provee de compuestos indispensables como carbohidratos, lípidos, proteínas. Es utilizada en la industria por su alto contenido de almidón. Debido a que el almidón es inestable a diversos factores, en la actualidad se ha optado por las modificaciones a los gránulos de almidón. Sin embargo, son pocos los estudios que han sido enfocados a las modificaciones que sufren los granos durante la germinación. Es por ello que se analizó la influencia de la germinación sobre los cambios morfológicos que se generan en los gránulos de almidón de cebada (variedad Esmeralda y Perla).

\section{Palabras Clave:}

Cebada, germinación, almidón, modificación

\section{Introduction}

Barley (Hordeum vulgare) belongs to the family of grasses, is an annual monocotyledonous plant [1]. It grows best in cool and moderately dry climates. It requires little accumulation of heat to mature, it can be planted at different altitudes and geographical areas; it is adapted to many environmental conditions [2]. Barley is a crop that is widespread throughout the world, occupying the fourth place on the sown surface, after wheat, corn and rice. It is one of the seeds of great industrial utility, in the food, the indispensable compounds like carbohydrates (mainly the starch), lipids, proteins. Barley is used mainly in the malting and baking industry for its high starch content [3]. Most of the endosperm is constituted for the most part by large, devitalized cells, provided with large and small starch granules (bimodal). The starch granules are coated with protein and some fat [4].

Starch is a semicrystalline polymer of glucose, consisting of two primary structures, amylose, which is a linear polymer with a-D- (1-4) bonds, and amylopectin, which is a branched polymer with $\alpha-D$ bonds. - (1-4) and $\alpha-D-(1-6)$. Of these two polymers, the main constituent of starch is amylopectin, the exact

Autor de Correspondencia, Universidad Autónoma del Estado de Hidalgo, Instituto de Ciencias Agropecuarias, Email: jackylaugo@gmail.com, fabiguzman01@yahoo.com.mx *,almadeliaroman@yahoo.com.mx, heurjupa@gmail.com 
fraction being determined by the botanical origin [5]. The proportion of these two polymers varies according to the botanical source and their physical organization within the granular structure, conferring unique physical and chemical properties to starch [6].

Because the starch presents a high degradation, a high viscosity in solution (water), thermal decomposition, insoluble in cold water and its chemical and mechanical properties has certain restrictions in its application in the industry, that is why it has been chosen and the modifications to the starch granules are increasing, whether physical, chemical, enzymatic, microbiological or the combination of these to improve the functionality and expand the uses of this. This work presents the evaluation of the microstructural changes that the starch granule undergoes in the barley, during the germination of eight days to controlled conditions analyzing its functional and physicochemical properties.

\section{RESULTS}

\section{Morphological characterization of starch granules.}

The micrographs obtained for the starch of germinated barley grain and ungerminated for the variety Esmeralda and Perla (see Figure 1) allowed us to observe that in both ungerminated varieties (Figure $1 \mathrm{a}$ and d) starch granules are observed in a lenticular form, smooth surface and of bimodal size, embedded in a protein matrix, said characteristics belong to a starch of barley based on that reported by Cantellano et al. [3]. The sample germinated for 4 days of the Esmeralda variety and the 5 days in Pearl showed small pores on the surface (Figure $1 \mathrm{~b}$ and e), which indicates that as the germination process progresses, the enzymatic activity increases [7]. At the end of the gemination (day 8) starch granules were no longer observed in the Esmeralda variety, this may be because they were completely hydrolyzed, however for the Pearl variety some starch granules with a rough surface were observed because of the enzymatic hydrolysis.

\section{Enzymatic activity: amylase and protease}

Enzymatic activity (see Table 1) in both varieties of barley increases as the germination time passes. The activity of the protease releases the starch granules of the protein matrix, in the case of amylase, it showed greater activity on day 4 for the Esmeralda variety, while in Pearl it was day 5 of the germination process. According to the obtained in the scanning micrographs, the appearance of pores in the surfaces of the starch granules correspond to the increase in the enzymatic activity of the amylase during germination [7]. The amylase activity for the Esmeralda variety was higher, so the starch was hydrolyzed faster as observed at day 8 in the micrographs.

\begin{tabular}{|c|c|c|c|c|}
\hline \multirow{4}{*}{ Table 1. Amylase and protease activity } \\
\hline \multirow{2}{*}{ Sample } & \multicolumn{2}{|c|}{ Perla } & \multicolumn{2}{c|}{ Esmeralda } \\
\cline { 2 - 5 } & Amylase & Protease & Amylase & Protease \\
\hline S/G & $4.21 \pm 0.01^{d}$ & $6.88 \pm 0.04^{c d}$ & $1.54 \pm 0.01^{d}$ & $6.35 \pm 0.09^{\mathrm{a}}$ \\
\hline Day1 & $3.94 \pm 0.03^{\mathrm{d}}$ & $5.98 \pm 0.04^{\mathrm{d}}$ & $2.37 \pm 0.02^{\mathrm{d}}$ & $5.11 \pm 0.03^{\mathrm{a}}$ \\
\hline Day 2 & $6.53 \pm 0.05^{\mathrm{bc}}$ & $5.75 \pm 0.02^{\mathrm{d}}$ & $4.97 \pm 0.03^{\mathrm{cd}}$ & $4.69 \pm 0.04^{\mathrm{a}}$ \\
\hline Day 3 $^{\mathrm{ab}}$ & $7.86 \pm 0.04^{\mathrm{b}}$ & $10.08 \pm 0.07^{\mathrm{b}}$ & $7.13 \pm 0.05^{\mathrm{b}}$ & $5.16 \pm 0.07^{\mathrm{a}}$ \\
\hline Day 4 & $6.42 \pm 0.00^{\mathrm{bc}}$ & $8.15 \pm 0.06^{\mathrm{bc}}$ & $10.55 \pm 0.14^{\mathrm{b}}$ & $5.61 \pm 0.01^{\mathrm{a}}$ \\
\hline Day 5 & $8.68 \pm 0.05^{\mathrm{a}}$ & $10.39 \pm 0.01^{\mathrm{b}}$ & $9.09 \pm 0.06^{\mathrm{b}}$ & $6.25 \pm 0.05^{\mathrm{a}}$ \\
\hline Day 6 & $5.78 \pm 0.04^{\mathrm{cd}}$ & $8.84 \pm 0.02^{\mathrm{bc}}$ & $9.59 \pm 0.01^{\mathrm{b}}$ & $7.07 \pm 0.04^{\mathrm{a}}$ \\
\hline Day 7 & $6.31 \pm 0.01^{\mathrm{bc}}$ & $12.95 \pm 0.04^{\mathrm{a}}$ & $8.50 \pm 0.06^{\mathrm{b}}$ & $7.41 \pm 0.02^{\mathrm{a}}$ \\
\hline
\end{tabular}

\section{Apparent amylose}

In Table 2, the values obtained for the apparent amylose content are expressed. At the beginning of germination, the percentage was $50.45 \%$ and $72.45 \%$ for the variety Perla and Esmeralda respectively, which is why they are considered amyl barley grains because of their high amylose content; the percentage of apparent amylose at day 8 decreased with respect to the initial one due to enzymatic hydrolysis and the growth of the radicle. 


\begin{tabular}{|c|c|c|}
\hline \multicolumn{3}{|c|}{ Table 2. Apparent amylose (\%) } \\
\hline Sample & Perla & Esmeralda \\
\hline S/G & $50.45 \pm 0.00^{\mathrm{a}}$ & $72.45 \pm 0.01^{\mathrm{a}}$ \\
\hline Day 1 & $46.64 \pm 0.01^{\mathrm{a}}$ & $66.27 \pm 0.00 \mathrm{c}^{\mathrm{a}}$ \\
\hline Day 8 & $27.58 \pm 0.02^{\mathrm{b}}$ & ${ }^{*}$ \\
\hline
\end{tabular}

* Not detectable

\section{Pasting properties}

Table 3 shows the data obtained on apparent viscosity, obtained by means of an RVA (rapid viscosity analyzer), which shows that if there are significant differences $(p<0.05)$ between each day of germination As the germination process progresses, the viscosity is decreasing for both varieties of barley because the total starch content decreases by the enzymatic hydrolysis of the amylase during germination [8], likewise Uthumporn et al. [9] report that a decrease in viscosity is due to the porous structure as it makes the starch granules more susceptible to hydrolysis; Pasting temperature is decreasing, indicating the presence of short chains with polymerization degree (DP) $<10$ since they decrease the stability of double helix in amylopectin molecules, decreasing the temperature of gelatinization, since the structure of amylose and amylopectin plays an important role in the sticking properties of starches [7].

\begin{tabular}{|c|c|c|}
\hline \multicolumn{3}{|c|}{ Tabla 3. Pasting properties } \\
\hline Perla variety & $\begin{array}{c}\text { Maximum viscosity } \\
\text { (cP) }\end{array}$ & $\begin{array}{c}\text { Pasting } \\
\text { temperature }\left({ }^{\circ} \mathbf{C}\right)\end{array}$ \\
\hline S/G & $3101 \pm 25^{\mathrm{a}}$ & $95.425 \pm 0.02^{\mathrm{a}}$ \\
\hline Day 2 & $2443 \pm 48^{\mathrm{b}}$ & $95.425 \pm 0.02^{\mathrm{a}}$ \\
\hline Day 4 & $1087 \pm 106^{\mathrm{c}}$ & $95.325 \pm 0.02^{\mathrm{b}}$ \\
\hline Day 6 & $503 \pm 20^{\mathrm{d}}$ & $95.275 \pm 0.02^{\mathrm{b}}$ \\
\hline Day 8 & $1079 \pm 118^{\mathrm{c}}$ & $95.075 \pm 0.02^{\mathrm{c}}$ \\
\hline $\begin{array}{c}\text { Esmeralda } \\
\text { variety }\end{array}$ & $\begin{array}{c}\text { Maximum viscosity } \\
(\mathbf{C P})\end{array}$ & $\begin{array}{c}\text { Pasting } \\
\text { temperature }\left({ }^{\circ} \mathbf{C}\right)\end{array}$ \\
\hline S/G & $2730.5 \pm 201.5^{\mathrm{a}}$ & $95.325 \pm 0.2^{\mathrm{ab}}$ \\
\hline Day 2 & $2338.5 \pm 23.5^{\mathrm{a}}$ & $95.375 \pm 0.03^{\mathrm{a}}$ \\
\hline Day 4 & $1880.5 \pm 70.5^{\mathrm{b}}$ & $95.2 \pm 0.10^{\mathrm{b}}$ \\
\hline Day 6 & $220 \pm 30^{\mathrm{c}}$ & $95.025 \pm 0.02^{\mathrm{c}}$ \\
\hline Day 8 & ${ }^{*}$ & ${ }^{*}$ \\
\hline
\end{tabular}

* Not detectable

\section{CONCLUSIONS}

The barley grain presents changes during the germination process: porosity, loss of shape, size and surface of the starch granules, which vary according to their content and the variety of barley. The viscosity of the starch is affected due to the hydrolysis of the starch granules and the amylose content. By subjecting the barley grain to a germination process its properties of the starch granules can be changed and therefore the use of this in the industry.

\section{References}

Colín R. M, Zamora V.VM, Lozano del Río AJ, Martínez Z. G, TorresT. MA. (2007) Caracterización y selección de nuevos genotipos imberbes de cebada forrajera para el norte y centro de México. Téc. Pec. Méx. 45(3): 249- 262.

SAGARPA, Secretaria de Agricultura, Ganadería, Desarrollo Rural y Pesca. (2016) Delegación de Hidalgo. www.siap.sagarpa.gob.mx.

Callejo, G. M.J. (2002) Malteria en: Industria de cereales y derivados. Mundiprensa 1ra edición. Madrid, España. PP. 169-185.

Van der Hesen. (2015) La cerveza: Ingredientes. http://caeliacerea.blogspot.mx/2015/03/ingredientes-i-la-cebada.html. Visto 24 de marzo del 2017.

Sajilata MG. Singhal RS. Kulkarni PR. (2006) Resistant starch-a review, Compr Rev Food Sci Food Saf; 5:1-17.

Tester, R. F., Karkalas, J., Qi, X. (2004) Starch-composition, fine structure and architecture. Journal of Cereal Science 39 151-165.

Singh N., Singh S., Isono, N, Noda T., Singh AM. (2009) "Diversity in amylopectin structure, thermal and pasting properties of starches from wheat varieties/lines". International Journal of Biological Macromolecules. Vol. 45, 298-304.

Zhu, L.J., Liu, Q.Q., Sang, Y., Gu, M.H., Shi, Y.C. (2010) Underlying reasons for waxy rice flours having different pasting properties. Food Chemistry 120, 94-100.

Uthumporn U, Zaidul ISM, Karim AA. (2010) Hydrolysis of granular starch at sub-gelatinization temperature using a mixture of amylolytic enzymes. Food Bioprod Process, 88:47-54. 